\title{
Yüksek dereceli servikal intraepitelyal neoplazi tanılı hastalarda konizasyon sonrası nüks gelişimini etkileyen faktörlerin değerlendirilmesi
}

\section{Evaluation of the factors affecting the development of recurrence after conization for high-grade cervical intraepithelial neoplasia diagnosis patients}

\author{
Mehtap YÜCEDAĞ ${ }^{1(D)}$, Talip KARAÇOR ${ }^{2 @(D)}$ Ateş KARATEKE $^{3(D}$ \\ ${ }^{1}$ Manisa Şehir Hastanesi, Kadın Hastalıkları ve Doğum Kliniği, 45040, Manisa-Türkiye \\ ${ }^{2}$ Adıyaman Üniversitesi, Tıp Fakültesi, Kadın Hastalıkları ve Doğum Anabilim Dalı, 02040, Adıyaman-Türkiye \\ ${ }^{3}$ Medeniyet Üniversitesi, Tıp Fakültesi, Kadın Hastalıkları ve Doğum Anabilim Dalı, 34720, İstanbul-Türkiye
}

Atıf gösterme/Cite this article as: Yücedağ M, Karaçor T, Karateke A. Yüksek dereceli servikal intraepitelyal neoplazi tanılı hastalarda konizasyon sonrası nüks gelişimini etkileyen faktörlerin değerlendirilmesi. ADYÜ Să̆llk Bilimleri Derg. 2021;7(1):X-X. doi:10.30569.adiyamansaglik.X

\section{Öz}

Amaç: Yüksek dereceli servikal intraepitelyal neoplazi (CIN) lezyonlarında konizasyon cerrahisi sonrası nüks riskini arttıran faktörlerin belirlenmesini amaçladık.

Gereç ve Yöntem: Yüksek dereceli CIN lezyonu olan yüz hastaya konizasyon cerrahisi uyguland. Aynı hastalara, bir yil sonra smear ve kolposkopik muayene yapıldı. Muayenede anormal bulgu tespit edilen hastalara biyopsi yapıldı. Biyopsi sonucunda yüksek dereceli CIN tespit edilen hastalar nüks pozitif, biyopsi sonucu normal gelen hastalar nüks negatif olarak belirlendi. Lezyonun nüksünü etkileyen faktörleri belirlemek için hastaların demografik verileri ve patolojik sonuçları incelendi.

Bulgular: Sigara içimi, glandüler tutulum, cerrahi sınıra 1,5 mm'den daha yakın lezyon varlığı ve lezyonun konizasyon materyalinin apeksine daha yakın yerleşik olması durumunda yüksek dereceli CIN lezyonlarının daha fazla nüks ettiği saptandı

Sonuç: Yüksek dereceli CIN lezyonlarında, konizasyon ve diğer ablatif cerrahi tedaviler sonrası, nüks edebilme riskinden dolayı bu hastaların takip ve tedavisi ciddi özen ile yapılmalıdır.

Anahtar Kelimeler: Servikal smear; Konizasyon; Neoplazi.

\begin{abstract}
Aim: We aimed to determine the factors that increase the risk of recurrence after conization surgery in highgrade cervical intraepithelial neoplasia (CIN) lesions. Materials and Methods: Conization surgery was performed on 100 patients with high-grade CIN lesions. Smear and colposcopic examinations were performed on the same patients one year later. Biopsy was performed in patients with abnormal findings on examination. Patients with high-grade CIN as a result of biopsy were identified as recurrence positive, and patients with no pathology after biopsy were identified as recurrence negative. Demographic data and pathological results of the patients were examined to determine the factors affecting the recurrence of the lesion.

Results: We found that high-grade CIN lesions relapse more frequently when smoking, glandular involvement, presence of lesions closer than $1.5 \mathrm{~mm}$ to the surgical margin and if the lesion was located closer to the apex of the conization material.

Conclusion: In high-grade CIN lesions, following conization and other ablative surgical treatments, follow-up and treatment of these patients should be done with great care because of the risk of recurrence.
\end{abstract}

Keywords: Cervical smear; Conization; Neoplasia.

Yazışma Adresi/Address for Correspondence: Talip KARAÇOR, Adıyaman Üniversitesi, Tıp Fakültesi, Kadın Hastalıkları ve Doğum Anabilim Dalı, 02040, Adıyaman-Türkiye, E-mail: talipkaracor@gmail.com

Geliş Tarihi/Received:18.11.2020 Kabul Tarihi/Accepted:12.02.2021

Yayım Tarihi/Published online:23.04.2021

Bu eser, Creative Commons Atıf-GayriTicari 4.0 Uluslararası Lisansı ile lisanslanmıştır. Telif Hakk1 (C) 2021 Adıyaman Üniversitesi Rektörlügü 


\section{Giriş}

Serviks, non-keratinize skuamöz epitel ve kolumnar epitel ile kaplıdır. Bu iki epitel tipinin birlessim yerine transformasyon zonu (TZ) denir. TZ'nin önemi serviks kanserinin öncül lezyonlarının genellikle bu bölgeden gelişmesidir. ${ }^{1}$ Ektoserviksi oluşturan çok katlı yassı epitelin atipik bir karakter kazanması ile servikal intraepitelyal neoplazi (Cervical Intraepithelial Neoplasia-CIN) oluşur. $\mathrm{Bu}$ anormal lezyon epitelin alt $1 / 3$ 'ünde sınırlı ise CIN I, alt 2/3'ünde ise CIN II, epitelin tamamına yakını kaplamışsa CIN III, tamamını içeriyorsa karsinoma in-situ (CIS) olarak adlandırılır. CIN lezyonları serviksin çok katlı yass1 epitelinde sinırlıdır. Epitel ile stromal tabakayı ayıran bazal memran atipik hücreler tarafından aşılmamıştır. Bazal memran atipik hücreler tarafından aşılması durumunda invaziv kanser tanısı alır. CIN I düşük dereceli intraepitelyal lezyon kabul edilirken, CIN II ve CIN III yüksek dereceli prekanseröz lezyonlar olarak kabul edilir. Yüksek dereceli kabul edilen CIN II ve CIN III ün tedavi edilmesi gerekmektedir. CIN II ve CIN III lezyonlarını tam anlamıyla ayırt etmek zordur. Bu nedenle bu iki lezyonun için tedavi önerileri benzerdir. ${ }^{2}$ $\mathrm{Bu}$ lezyonların tedavisinde ülkemizde ve tüm dünyada en sık kullanılan tedavi yaklaşımları loop elektrocerrahi eksizyon prosedür (LEEP) ve cold-knife' kon biyopsi (Konizasyon) ablasyon işlemleridir. Ablasyon yöntemlerinin uygulanmasindan sonra bu yüksek dereceli CIN lezyonlarının tekrar etme ihtimali vardır. Düşük sosyoekomik düzey, sigara, cinsel yolla bulaşan hastalıklar, parite, kullanılan kontrasepsiyon yöntemi gibi birçok faktör servikal intraepitelial lezyonların nüks etmesinde etkilidir. Ayrıca yapılan LEEP ve konizasyon gibi ablasyon yöntemlerinin uygun yapılması ve çıkarılan servikal materyaldeki lezyonun büyüklüğü yerleşim yeri ve yapısı da bu lezyonların nüks etmesinde etkilidir. $\mathrm{Bu}$ sebeple LEEP veya konizasyon cerrahi işlemi sonras1, hastalar yüksek dereceli CIN lezyonların nüksü açısından smear ve kolposkopik muayene ile takip edilmelidir. ${ }^{3}$ Mevcut çalışmamızda yüksek dereceli CIN (CIN II-III) nedeni ile konizasyon yaptığımız hastalarımızı, bir yıl sonra nüks açısından smear ve kolposkopik muayene ile tekrar değerlendirdik. Nüks pozitif ve nüks negatif hastalarda nüks gelişimini etkileyen demografik ve patolojik etmenleri değerlendirmeyi amaçladık.

\section{Gereç ve Yöntem}

Çalışma Zeynep Kâmil Kadın Doğum ve Çocuk Hastalıkları Eğitim ve Araştırma Hastanesi'nde retrospektif olarak yapıldı. Çalışmaya başlamadan önce hastanemiz yerel etik kurulundan 6708/21.04.2010 say1 numarası ile onay alındı. Çalışma WMA 64, Fortaleza, Brezilya, Ekim 2013 Genel Kurulunda alınan Helsinki İlkeler Deklarasyonu kararlarına uyularak kararlarına gerçekleştirildi. Hastanemizde 2005-2009 yılları arasında smear sonucu high-grade skuamöz intraepitelyal lezyon (HGSIL) ve kolposkopik biyopsi sonucu CIN III olup konizasyon yapılan hastalar çalışmaya dahil edildi. Çalışmaya dahil edilen tüm hastalardan bilgilendirilmiş onam alındı. Konizasyon operasyonundan sonra hastalar bir yıl sonra kontrole çağrıldı. Gebe hastalar ve konizasyon materyalinde invaziv serviks kanseri rapor edilen hastalar çalışmaya dahil edilmedi. Konizasyon materyalinin patoloji sonucunda, lezyon sınırında atipik hücre tespit edilen ve fertilite beklentisi olmayan hastalara histerektomi+frozen yapıldı. Smear ve kolposkopik muayene takibine cerrahi sınırda lezyon olmayan ve cerrahi sınıra $1.5 \mathrm{~mm}$ 'den daha az mesafede atipik hücre tespit edilen fakat yüksek fertilite beklentisi olan hastalar alındı. Ayrıca sınırdaki lezyonun CIN II-III ayrımı tam yapılamayan hastalar da smear ve kolposkopik muayene takibine alınd. Kontrole gelen ve belirtilen kriteri karşılayan 100 hasta çalışmaya dahil edildi. Tüm hastalar smear ve kolposkopik muayene ile tekrar değerlendirildi. Smearde patolojik bulgusu olan ve kolposkopik muayenede şüpheli alan gördügümüz 11 hastadan biyopsi alındı. Alınan servikal smearler papanicolaou ile boyand1 ve jinekopatoloji konusunda deneyimli hastanemiz jinekopatologları tarafından Bethesda 2001 sistemine göre değerlendirildi. Kolposkopik muayeneler bu konuda deneyimli Kadın Hastalıkları ve Doğum Uzmanı tarafından yapıldı. Spekulum takılmasını takiben servikse \%3'lük asetik asit uyguland. Kolposkopik incelemede bulgular, 
hastanemizde bulunan standart kolposkopi formu ile dökümante edildi. Kolposkopik anormalliklerden olan asetobeyaz epitel, mozaik patern, punktuasyon, atipik damarlanmalar aynı form üzerinde işaretlendi. Kolposkopik muayenede muhtemelen en patolojik görülen alanlardan biyopsiler alındı. Alınan biyopsiler tekrar jinekopatologlar tarafından değerlendirildi. Alınan yeni patolojik materyalde anormal bulgu izlenmeyen vakalar nüks negatif (Grup 1), CIN II, CIN III ve invaziv serviks kanseri tespit edilen vakalar nüks pozitif (Grup 2) kabul edildi. Nüks pozitif hastalarda hangi parametrelerin nüks riskini arttırdığını belirlemek için hastaların demografik özellikleri ve ilk konizasyon işlemindeki patoloji raporları incelendi. Patoloji raporlarında glandüler tutulum, konizasyon materyalinde lezyonun $1 / 2$ üst apekse yakın yerleşimi ve cerrahi sınıra 1,5 mm'den daha az mesafede atipik hücre varlığı not edildi. Koni şeklindeki patoloji materyali transvers hat ile ortadan ayırıldı, lezyonun \%50'i bu hattın üstünde ise apekse yakın, altında ise apekse uzak șeklinde belirtildi. Serviks kanseri ve CIN nüksü için risk faktörleri olan yaş, obstetrik durum, partner sayısı, ilk ilişki yaşı, kondom, oral kontraseptif (OKS), rahim içi araç (RİA) kullanıp kullanmadığı, tüp ligasyon öyküsü ve sigara alışkanlığı soruldu.

Verilerin istatistiksel analizi, Statistical Package for the Social Sciences 15.0 (SPSS Inc., Chicago, IL, ABD) kullanılarak hesapland1. Verilerin değerlendirilmesinde tanımlayıc1 istatistiksel metotların (ortalama, standart sapma) yanı sira ikili grupların karşılaştırmasında bağımsız $t$ testi, nitel verilerin karşılaştırmalarında ki-kare $\left(x^{2}\right)$ testi kullanıldı. Sürekli değişkenler ortalama \pm standart sapma (SD) ile sunuldu. Nüks pozitifliğini etkileyen faktörleri belirlemek için lojistik regresyon analizi yapıldı. Sonuçlar $p<0,05$ düzeyinde anlamlı kabul edildi, \%95'lik güven aralığında değerlendirildi.

\section{Bulgular}

Smear sonucu HGSİL olan 32, kolposkopik biyopsi sonucu CIN III olan 68, toplam 100 hastaya konizasyon (cold-knife) yapıldı. Nüks negatif (Grup 1) ve nüks pozitif (Grup 2) hastaların demografik verileri Tablo 1'de verildi. Grup 1 ve Grup 2 arasında yaş, gravida, parite ve ilk ilişki yaşı açısından istatistiksel fark saptanmadi $(p>0.05)$.

Tablo 1. Gruplar arasındaki demografik verilerin karşılaştırılması.

\begin{tabular}{|c|c|c|c|}
\hline & $\begin{array}{l}\text { Grup } 1 \\
\mathrm{n}: 86\end{array}$ & $\begin{array}{l}\text { Grup } 2 \\
\mathrm{n}: 14\end{array}$ & $p$ \\
\hline Yaş & $38,12 \pm 6,68$ & $41 \pm 10,7$ & 0,176 \\
\hline Gravida & $2,95 \pm 1,9$ & $3,29 \pm 2,56$ & 0,565 \\
\hline Parite & $2,2 \pm 1,24$ & $2,07 \pm 1,64$ & 0,736 \\
\hline İlişki & & & \\
\hline Yaş1 & $18,95 \pm 3,27$ & $17,86 \pm 3,28$ & 0,248 \\
\hline
\end{tabular}

Yüksek dereceli CIN nüksüne etki eden parametreler Grup 1 ve Grup 2 arasinda karşılaştırıldığında, hastanın 35 yaş üstünde veya altında olmasının yüksek dereceli CIN nüksüne etki etmediği görüldü. Ayrıca hastaların kontrasepsiyon yöntemi kullanıp kullanmaması ve hastaların kullandığ kontrasepsiyon türünün yüksek dereceli CIN nüksüne etki etmediği görüldü (sırasıyla $p$ değerleri 0,786 ve 0,535). Sigara içimi, konizasyon materyalinde lezyonun cerrahi sınıra 1,5 mm'den daha yakın olması, glandüler tutulum ve lezyonun konizasyon materyalinde apekse yakın yerleşimli olması yüksek dereceli CIN'ların daha yüksek oranda nüks etmelerine neden olduğu bulundu (sirasiyla $p$ değerleri; 0,023, 0,014, 0,004, $0,003)$. Konizasyon sonrası yüksek dereceli CIN nüksüne etki eden parametreler Tablo 2'de özetlenmiştir.

Konizasyon sonrası nüks pozitif olan hastalarda istatistiksel olarak daha yüksek saptanan sigara içimi, konizasyon materyalinde glandüler tutulum, cerrahi sınıra 1,5 mm'den daha yakın lezyon varlığı ve lezyonunu patolojik materyalde apekse yakın yerleşimli olmasının nüks pozitifliği üzerine etkisini değerlendirmek için lojistik regresyon analizi yapıldı. Sigara içmek $(p=0,015)$ ve lezyonunun patolojik materyalde apekse yakın yerleşimli olmasının $(p=0,011)$ nüks pozitifliğini etkileyen faktörler olarak belirlendi. Belirtilen parametrelere ait lojistik regresyon analizi Tablo 3 'te özetlenmiştir. 
Tablo 2. Konizasyon sonrası yüksek dereceli CIN nüksüne etkisi karşılaştırılan parametreler

\begin{tabular}{|c|c|c|c|c|c|}
\hline & & $\begin{array}{c}\text { Grup } 1 \\
\mathrm{n}: 86\end{array}$ & $\begin{array}{c}\text { Grup } 2 \\
\mathrm{n}: 14\end{array}$ & & OR (\%95 GA) \\
\hline \multirow{2}{*}{ Yaş } & $<35$ Yaş & $34(\% 39,50)$ & $5(\% 35,70)$ & $\chi^{2}: 0,07$ & 1,77 \\
\hline & $>35$ Yaş & $52(\% 60,50)$ & $9(\% 64,30)$ & $p=0,786$ & $0,36-3,81$ \\
\hline \multirow{2}{*}{ Sigara } & Yok & $63(\% 73,30)$ & $6(\% 42,90)$ & $\chi^{2}: 5,2$ & 3,65 \\
\hline & Var & $23(\% 26,70)$ & $8(\% 57,10)$ & $p=0,023$ & $1,14-11,67$ \\
\hline \multirow{2}{*}{$\begin{array}{l}\text { Glandüler } \\
\text { Tutulum (Eski) }\end{array}$} & Yok & $73(\% 84,90)$ & $8(\% 57,10)$ & $\chi^{2}: 6,02$ & 4,21 \\
\hline & Var & $13(\% 15,10)$ & $6(\% 42,90)$ & $p=0,014$ & $1,25-14,15$ \\
\hline \multirow{3}{*}{ Kontrasepsiyon } & Kullanmiyor & $18(\% 20,90)$ & $3(\% 21,40)$ & & \\
\hline & $\mathrm{OKS}$ & $25(\% 29,10)$ & $6(\% 42,90)$ & $\chi^{2}: 1,25$ & $1,44(0,32-6,54)$ \\
\hline & Diğer & $43(\% 50,0)$ & $5(\% 35,70)$ & $p=0,535$ & $0,70(, 15-3,23)$ \\
\hline \multirow{2}{*}{$\begin{array}{l}\text { Cerrahi sınıra } 1.5 \\
\text { mm'den yakın } \\
\text { lezyon }\end{array}$} & Yok & $78(\% 91,80)$ & $9(\% 64,30)$ & $\chi^{2}: 8,52$ & 6,19 \\
\hline & Var & $7(\% 8,20)$ & $5(\% 35,70)$ & $p=0,004$ & $1,62-23,63$ \\
\hline \multirow{2}{*}{$\begin{array}{l}\text { Apekse yakın } \\
\text { yerleşimli lezyon }\end{array}$} & Yok & $68(\% 80,00)$ & $6(\% 42,90)$ & $\chi^{2}: 8,79$ & 5,33 \\
\hline & Var & $17(\% 20,00)$ & $8(\% 57,10)$ & $p=0,003$ & $1,63-17,44$ \\
\hline
\end{tabular}

Tablo 3. Yüksek dereceli CIN lezyonlarında nüks pozitifliğini etkileyen faktörlerin lojistik regresyon analizi.

\begin{tabular}{lcccccc}
\hline & B & S.E. & $p$ & OR & Lower & Upper \\
\hline Sigara & $-1,89$ & 0,78 & 0,015 & 0,16 & 0,33 & 0,70 \\
\hline Glandüler Tutulum Eski & $-1,11$ & 0,70 & 0,114 & 0,33 & 0,84 & 1,31 \\
\hline $\begin{array}{l}\text { Cerrahi sinıra 1.5 mm'den yakın } \\
\text { lezyon }\end{array}$ & $-1,21$ & 0,79 & 0,126 & 0,29 & 0,63 & 1,41 \\
\hline $\begin{array}{l}\text { Apekse yakın yerleşimli lezyon } \\
\text { Constant }\end{array}$ & $-1,99$ & 0,78 & 0,011 & 0,14 & 0,03 & 0,63 \\
\hline
\end{tabular}

\section{Tartışma}

Serviks kanseri, yaygınlaşan smear ve kolposkopi tarama yöntemleri ve saptanan servikal intraepitelyal lezyonlarm uygun tan 1 ve tedavisi ile azalma eğilimindedir. Prekanseröz lezyonların takip ve tedavisi hastanın fertilite isteğine, premenopozmenopoz durumuna, aile öyküsüne ve takip edilebilme kabiliyetine bağlı olarak değişir. Ayrıca prekanseröz lezyonların tanı ve tedavisi için uygulanan LEEP ve konizasyon gibi işlemler sonucunda çıkan patoloji sonuçlarıda takip ve tedavi planlamasında etkilidir. ${ }^{4}$ Yapılan çalışmalarda serviks kanseri en sık 5060 yaş aralığında görülmektedir. Ülkemizde de invaziv serviks kanserlerinin \%65'i 40-60 yaş grubunda görülmektedir. ${ }^{5}$ Çalışmamızda konizasyon yapılan hastaların yaş ortalaması benzer idi. Takipte nüks eden ve nüks etmeyen gruplar arasındaki yaş ortalaması istatistiksel olarak benzer bulundu. Literatürde çalışmamıza benzer veya farklı yaş ortalamaları ve sonuçların rapor edildiğ $i$ görülmüştür. $^{6} \quad \mathrm{Bu}$ farklılıklar çalışma merkezlerinin yapıldığ 1 toplumlardaki sosyokültürel yap1 ve sosyoekonomik gelişmişlikle alakalı olduğunu düşünüyoruz. Literatürde kanser riskini arttırıcı etkisi ilk olarak tanımlanan risk faktörlerinden birisi paritedir. Çok doğum yapan kadınlarda hipertrofiye olmuş serviksin silindirik epitelinin portioya dönmesi ve erken yass1 epitel metaplazi gelişmesinin, risk artışında sorumlu olabileceği öne sürülmektedir. ${ }^{7}$ Term gebelik oranları arttıkça riskin de buna paralel olarak arttığ 1 saptanmıştır. Her bir term gebelik ile serviks kanseri riski 1,13 kat artmaktadır. ${ }^{8}$ Biz çalışmamızda iki grup arasında parite açısından istatistiksel olarak fark saptamadık. Çalışmamızda kontrasepsiyon yöntemlerinin konizasyon işlemi sonrası prekanseröz CIN III lezyonlarının nüksü üzerine etkisi olmadığını saptadık. Bazı çalışmalarda oral kontrasepsiyon kullanımının villoglandüler tip serviks kanserini arttırdığın19, kondom kullanımının ise skuamöz tip serviks kanseri riskini azalttığ 1 bildirilmiştir. ${ }^{10}$ Çalışmamızda kontrasepsiyon yöntemleri arasında CIN nüksü açısından fark olmamasını hastaların yaş ve parite ortalamalarının benzer olmasına ayrica tek partnerli cinsel yaşam tercihlerine bağladık. Sigara içiminin konizasyon sonrası CIN III nüksünü arttırdığını bulduk. Sigara 
kullanımının servik kanseri için risk faktörü olduğu birçok çalışmada gösterilmiştir. ${ }^{11}$ Sigaranın serviks kanserinin bilinen en önemli risk faktörü olan HPV virüsünün vücutta elimine edilmesini azalttığı böylece serviks kanseri riskini ve tedavi sonrası nüks riskini arttırdığ 1 bildirilmiştir. ${ }^{12}$ Hatta Zeng ve ark. pasif içiciliğin bile serviks kanseri riski için önemli olduğunu bildirmişlerdir. ${ }^{13}$ Çalışmamızda, konizasyon materyalinde glandüler tutulum olan vakalarda daha fazla nüks olduğu görüldü. Hastalarda glandüler tutulumun yüksek dereceli CIN nüksünü 4,2 kat artırdığı saptandi. Konizasyon materyalinde glandüler hücre tutulumu varlığında, konizasyon materyali sınırında atipik glandüler hücre olmasa bile, materyal dışındaki farklı bir komşu glandüler yapıda atipik hücre varlığı olabilir. ${ }^{14} \mathrm{Bu}$ sebeple konizasyon materyalinde glandüler hücre tutulumu varsa, bu hastalarda yüksek dereceli CIN nüksü riski daha yüksektir. Literatürde yapılan araştırmalarda da glandüler tutulumun olduğu vakalarda \%23,6 oranında nüks olduğu, glandular tutulumu olmayan vakalarda ise nüks oranı $\% 11,3$ saptanmıştır. ${ }^{15}$ Çalışmamızda konizasyon materyali sınırana 1,5 mm'den daha yakın atipik hücre varlığında, yüksek dereceli $\mathrm{CIN}$ nüksünün daha fazla olduğu saptandı $(\% 35,7)$. Cerrahi sinırı negatif fakat cerrahi sinıra $1,5 \mathrm{~mm}$ 'den daha yakın atipik hücre tespit edilen hastalardan yüksek fertilite beklentisi ve sinırdaki lezyonun CIN II-III ayrımı tam yapılamayan hastalar, nüks oranının yüksek olabileceği hakkında bilgilendirilerek smear ve kolposkopik muayene takibine alınmıştı. Beklendiği gibi yüksek bulundu. Literatürde de benzer şekilde fertilite arzusu olan ve sinırda lezyonda CIN II-III ayrımı tam yapılamayan hastaların takibe alındığını gördük. ${ }^{16}$ Çünkü CIN II ve CIN III lezyonlarını histolojik olarak tam ayırt etmek zordur. CIN II lezyonlarının takip esnasinda CIN III lezyonlarına göre daha fazla gerileme gösterme eğilimi vardır. ${ }^{16}$ CIN II-III lezyonlarda kısa sürede gerçekleşen in-vitro fertilizasyon gebeliği sonrası tekrar değerlendirme ve sonuca göre tedavi modelinin belirlenmesi literatürde mevcuttur. ${ }^{17}$ Cerrahi sinıra yakın ve CIN II-III ayrımı tam yapılamayan hastalarda, nüks riski ve olası diğer riskler hakkında bilgilendirme yapılarak takip kararı alındı. Gördük ki gebelik oluşmayan ve kontrol smear ve kolposkopik muayene sonucunda cerrahi sinırda lezyon olmasa bile cerrahi sinıra $1,5 \mathrm{~mm}$ 'den daha kısa mesafede atipik hücre varlığının yüksek dereceli CIN lezyonlarında nüks riskini yükseltmektedir. Nüks riskini arttıran başka bir faktör de, lezyonun konizasyon materyalinin apeksine daha yakın yerleşik olması idi. Serviks epitelinin ektoserviksten endoservikse doğru skuamöz epitelden kolumnar epitele döner. ${ }^{18} \mathrm{Bu}$ nedenle konizasyon materyalinin apeksine yakı lezyonlarda patolojik incelemede tespit edilemese dahi daha fazla glandüler hücrelerin olma ihtimali olduğunu düşünüyoruz. Ayrıca konizasyon materyalinin apeksine yakın lezyonların sinırlarını tam olarak ayırt etmek, materyalin tabanına göre daha zor olacağı kanaatindeyiz. Baiocchi ve arkadaşlarının yaptığı çalışmada da koni materyalinde lezyon endoservikse ne kadar yakınsa konizasyon sonrası yapilan histerektomide rezidü lezyon varlığı o kadar yüksek saptanmıştır. ${ }^{19}$ Birçok faktörün yüksek dereceli CIN lezyonlarının tekrarlama riskini arttırdığı literatürde paylaşılmıştır. ${ }^{20}$ Mevcut çalışmamızda sigara içimi, glandüler tutulum, cerrahi sınıra 1,5 mm'den daha yakın lezyon varlığı ve lezyonun konizasyon materyalinin apeksine daha yakın yerleşik olması yüksek dereceli CIN lezyonlarının daha fazla nüks ettiği saptandı. İki grup arasında istatistiksel olarak anlamlı fark saptanan parametrelerin nüks riskine etkisini değerlendirmek için lojistik regresyon analizi yaptık. Sigara içmek $(p=0,015)$ ve lezyonun konizasyon materyalinin apeksine yerleşik olmasının $(p=0,011)$ nüks pozitifliğini etkileyen faktörler olarak belirledik. Sigara içiminin yukarda da belirttiğimiz gibi serviks kanseri ve öncü lezyonları için bilinen en önemli risk faktörü olan HPV ajanının eliminasyonunu azalttığ 1 için serviks kanseri öncü lezyonlarının yüksek dereceli CIN nüksünü arttırmaktadır. ${ }^{12}$

Lezyonun konizasyon materyalinde apekse yakın yerleşmesi hem glandüler hücrelere daha yakın olması hem de apekse yakın lezyonlarda cerrahi sınır değerlendirmesinin daha net yapılamadığından dolay yüksek dereceli CIN nüksünü arttırdığını düşünüyoruz. 
Çalışmamızın önemli kısıtlılıklarından biri, yüksek dereceli CIN lezyonu bulunan hastaların human papilloma virüs (HPV) tiplendirilmesinin yapılmamış olmasıdır. Diğer kısıtlayıcı durumlar ise; CIN lezyonu boyutunun, rekürrens riskini etkileyip etkilemediği konusunda çalışmamızda veri bulunmamasıdır. Ayrıca nüks negatif olan hastaların bir yıldan sonraki dönemlerde akıbetinin bilinmemesi de çalışmamızın kısıtlılıklarından biridir.

Çalışmamızın güçlü yönlerinin ilk sırasında, çalışmanın tek merkezde yapılımış ve hastaların aynı bölgede homojen popülasyon olması gelmektedir. Böylece CIN lezyonlarında nüks riskini belirlemede, değerlendirilen kriterler dişındaki etmenler minimalize edilmiş olur. Ayrıca tüm patolojik örneklerin aynı laboratuvarda çalışılmış olması ve hastaların 12 ay takip edilmesi çalışmanın diğer güçlü yönleridir.

\section{Sonuc}

Çalışmamızda sigara içimi ve yüksek dereceli CIN lezyonunun konizasyon materyalinin apeksine yerleşik olmasının, lezyonun nüks ihtimalini arttırdığı bulundu. $\mathrm{Bu}$ bulgular, güncel literatürü destekler niteliktedir. Yüksek dereceli CIN lezyonlarında yapılan konizasyon işlemi lezyonu tamamen çıkarmış olsa bile bazı durumlarda hastalık nüks edebilir. Bu sebeple yüksek dereceli CIN lezyonlarının takip ve tedavisi ciddi özen ile yapılmalıdır.

\section{Araştırmanın Etik Boyutu}

$\mathrm{Bu}$ çalışmanın etik onayı hastanemizin Bilimsel Araştırma Etik Kurulu'ndan 21/04/2010 tarih ve 6708 karar sayısı ile etik kurul izni alınmıştır. Etik kurul kararı dosyalara eklenmiştir.

Araştırma Helsinki Bildirgesi ilkelerine göre yürütülmüştür.

\section{Bilgilendirilmiş onam}

Çalışmaya katılan tüm hastalardan cerrahi bilgilendirilmiş onam alınmıștır.

\section{Yazar katkıları}

MY: Olguları toplama, istatistiksel analiz, ana metni gözden geçirme; TK: Ana metni gözden geçirme, makaleye son halini verme; AK: Çalışma planı ve dizaynı.

\section{Çıkar çatışması beyanı}

Yazarların herhangi bir çıkara dayalı ilişkisi yoktur.

\section{Araştırma desteği}

Çalışmayı maddi olarak destekleyen herhangi bir kurum/kuruluş/kişi yoktur.

\section{Hakem Değerlendirmesi}

Diş bağımsız.

\section{Kaynaklar}

1. Dağlı AF, Özercan MR. Servikal Smear Tarama Programımızda Sinırlılık/Yetersizlik Oranları ve Nedenleri (1322 Olgu). Firat Tip Dergisi 2006;11(3):166-169.

2. Wright TC, Massad LS, Dunton CJ, Spitzer M, Wilkinson EJ, Solomon D. 2006 consensus guidelines fort he management of women with cervical intraepithelial neoplasia or adenocarcinoma in situ. Am J Obstet Gynecol. 2007;3:40-45.

3. Duggan BD, Felix JC, Muderspach LI, Gebhardt JA, Groshen S, Morrow $\mathrm{CP}$, et alCold-knife conization versus conization by the loop electrosurgical excision prosedüre: a randomized, prospective study. Am J Obstet Gynecol. 1999;180:276-82.

4. Ferlay J, Steliarova-Foucher E, Lortet-Tieulent J, et al. Cancer incidence and mortality patterns in Europe: estimates for 40 countries in 2012. Eur J Cancer, 2013;49:1374-403.

5. T.C. Sağlık Bakanlığı Sağlık İstatistikleri Yıllığı 2015. Yayın No:1054. Ankara: Sistem Ofset Basım Yayın; 2016. ss.36-7.

6. Bray F, Loos AH, McCarron $\mathrm{P}$ et al. Trends in cervical squamous cell carcinoma incidence in 13 European countries: changing risk and the effects of screening. Cancer Epidemiol Biomarkers Prev. 2005;14: 677-86.

7. Patnick J. Cervical cancer control in Europe. CME Journal of Gynecologic Oncology. 2000;5: 8-12

8. Yüce K. Serviks Kanserinde Risk Faktörleri. Klinik Aktüel Tip Dergisi. 2007;12:46-50.

9. Korach J, Machtinger R, Perri T, et al. Villoglandular papillary adenocarcinoma of the uterine cervix: a diagnostic challenge. Acta Obstet Gynecol Scand. 2009;88(3):355-358.

10. Parazzini F, Negri E, La Vecchia C, Fedele L. Barrier methods of contraception and the risk of cervical neoplasia. Contraception. 1989;40(5):519-30.

11. Castellsagué X, \& Munoz N. Chapter 3: Cofactors in human papillomavirus carcinogenesis role of parity, oral contraceptives, and tobacco smoking. JNCI monographs. 2003;31:20-28.

12. Lacey JV Jr, Frisch M, Brinton LA, Abbas FM, Barnes WA, Gravitt PE, et al. Associations between smoking and adenocarcinomas and squamous cell carcinomas of the uterine cervix. Cancer Causes Control. 2001;12:153-61.

13. Zeng XT, Xiong PA, Wang F, Li CY, Yao J, Guo Y. Passive smoking and cervical cancer risk: a meta-analysis based on 3,230 cases and 2,982 controls. Asian Pac J Cancer Prev. 2012;13(6):2687-93.

14. The Pap test and Bethesda 2014. Nayar R, Wilbur DC. Cancer Cytopathol. 2015;123(5):271-81.

15. Burki TK. Atypical glandular cells and risk of cervical cancer. Lancet Oncol. 2016;17(3):e96

16. Mitchell MF, Tortolero-Luna G, Wright T, Sarkar A, Richar-dsKortum R, Hong WK. Cervical human papillomavirus infection and intraepithelial neoplasia: a review. J Natl Cancer Inst Monogr 1996;21:17-25.

17. Jakobsson M, Gissler M, Tiitinen A, Paavonen J, Tapper AM, Treatment for cervical intraepithelial neoplasia and subsequent IVF deliveries, Human Reproduction, 2008, 23(10), 2252-2255.

18. Hwang LY, Ma Y, Benningfield SM, Clayton L, Hanson EN, Jay J, Jonte J, Godwin de Medina C, Moscicki AB. Factors that influence the rate of epithelial maturation in the cervix in healthy young women. J Adolesc Health. 2009;44(2):103-110. 
19. Baiocchi G, Bovolim G, Goncalves B, et al 146 Predictive factors for residual disease after cone biopsy in cervical cancer: a matter of margin distance? International Journal of Gynecologic Cancer 2019;29:A67.

20. Kashyap N, Krishnan N, Kaur S, Ghai S. Risk Factors of Cervical Cancer: A Case-Control Study. Asia Pac J Oncol Nurs. 2019;6(3):308-314 